\title{
STUDY ON THE INTEGRATION OF THE EXIGENCIES OF ACCOUNTING REGULATIONS IN THE ACCOUNTING PRACTICE OF ROMANIAN COMPANIES
}

\author{
Elena-Iuliana Ion ${ }^{1}$ \\ Mariana $\mathrm{Man}^{2}$
}

\begin{abstract}
This paper presents specialists' perception regarding the importance of integrating the exigencies of the accounting regulations in the accounting practice in Romanian companies, in order to faithfully appreciate the position and financial performance of companies. The results of the research shows that a large proportion of respondents affirm that the exigencies of the accounting regulations are integrated in the accounting practice within the company in order to meet the requirements of all information users. Most of those surveyed consider that the company's performance is closely related to satisfying the customers, employees, investors and users of financial-accounting information. The research shows that integrating the exigencies of the accounting regulations into the accounting system increases the companies' level of responsibility The research aims to emphasise the importance of integrating the exigencies of the accounting regulations into the company's accounting system in order to accurately assess the financial performance and increase the companies' level of social responsibility.
\end{abstract}

Keywords: performance, exigencies of accounting regulations, company

JEL Classification: M40, M41,M49

\section{Introduction}

Currently, the Romanian companies prepare annual financial statements in compliance with the exigencies of the accounting regulations harmonised with the European and international reference. Taking into account the exigencies of the accounting regulations applied, Romanian companies classify into two categories:

- companies that apply the exigencies of the accounting regulations in compliance with the Directive 2013/34/EU - the European Accounting Directive, approved of by the Order of the Minister of Public Finance (MPF) no. 1802/2014, for approving the accounting Regulations on the annual individual financial statements and consolidated annual financial statements, with further additions and amendments;

- companies that apply the exigencies of the accounting regulations in compliance with the International Financial Reporting Standards (IFRS) approved of by the Order of the Minister of Public Finance (MPF) no. 2844/2016 for approving the Accounting Regulations compliant with the International Financial Reporting Standards (IFRS).

In the context of applying the exigencies of the accounting regulations compliant with the Directive 2013/34/EU, three categories of entities are defined, respectively: micro-entities, small entities, medium and large entities. The categories of entities specified have different liabilities in terms of the accounting reporting requirements.

\footnotetext{
${ }^{1} \mathrm{PhD}$. Student Ec., Craiova University, Faculty of Economics and Business Administration, tel. +40764349433, Email: ion_elena_iuliana@yahoo.com

${ }^{2}$ Professor Phd., PetroȘani University,Faculty of Sciences, tel. +40722763360, Email: man_mariana2006@yahoo.com
}

DOI: 10.29302/oeconomica.2017.19.2.5 
In order to prepare the annual financial statements, companies carry out the classification into size criteria at the end of the financial year, stipulated by the accounting regulations in force. In this regard, the determining indicators from the financial statements of the financial year prior to the one ended are determinative, as well as the determinative indicators at the end of the financial year are all taken into account. If in two consecutive financial years the entity exceeds or ceases to exceed the size criteria, then it changes the category in which it is classified.

The indicators depending on which the size criteria are established are: total assets, the net turnover and average number of employees throughout the financial year. (Order of the MPF no. $1802 / 2014$, for approving the accounting Regulations on the annual individual financial statements and consolidated annual financial statements, with further additions and amendments).

Unlike the accounting regulations approved of by the Order of the MPF no. 1802/2014, where standardised accounting treatments are specified, the IRF's are largely based on professional reasons. Currently, regarding the Order of the MPF no. 2844/2016 for approving the Accounting Regulations compliant with the International Financial Reporting Standards (IFRS), the following categories of entities prepare a set of individual annual financial statements based on the accounting regulations compliant with the IFRS:

- entities whose securities are admitted at trading on a regulated market;

- the legal entities specified by the Order of the MPF no. 666/2015 on applying the Accounting Regulations compliant with the International Financial Reporting Standards by some entities with public capital.

- $\quad$ other entities required by legal provisions to apply those regulations;

- other entities that have opted for applying those regulations (conditions in which they can opt being set forth by legal provisions).

According the provisions included in the IFRS, the entities prepare the verification balance that includes information according to the Accounting Regulations on the individual annual financial statements and consolidated annual financial statements, approved of by the Order of the MPF no. 1802/2014, along with recording the reprocessing operations in the accounting system, which determine the acquirement of the verification balance that includes information according to the IFRS provisions. (Order of the MPF no. 2844/2016 for approving the Accounting Regulations compliant with the International Financial Reporting Standards (IFRS)).

In 2014, the number of companies that applied the accounting regulations compliant with the IFRS was equal to 71. (Petre G. and Pavel N., 2015).

Since 2015, certain entities with public capital were required to prepare a set of information based on the IFRS for the financial years 2016 and 2017, to keep their accounting records according to the IFRS provisions as of the financial year of 2018. (Order of the MPF no. 666/2015 on applying the Accounting Regulations compliant with the International Financial Reporting Standards (IFRS) by some entities with public capital).

As of January $1^{\text {st }}, 2016$, the authorised entities, regulated and supervised by the Financial Supervisory Authority in the Sector of Financial Instruments and Investments (FSA SFII) shall keep the accounting records in compliance with the IFRS and shall prepare and publish individual and consolidated annual financial statements in compliance with the IFRS. (The instruction no. 1/2015, for amending and complementing the Instruction no. 2/2014 on the application of the International Financial Reporting Standards by the authorised entities, regulated and supervised by the Financial Supervisory Authority in the Sector of Financial Instruments and Investments (FSA SFII))

Within the Dolj County, most companies prepare annual financial statements in compliance with the accounting regulations approved of by the Order of the Minister of Public Finance (MPF), no. 1802/2014, for approving the accounting Regulations on the annual individual financial statements and consolidated annual financial statements, with further additions and amendments. A low number of companies, located in Dolj County, applies the exigencies of the accounting regulations according to the IFRS, of which we list the following: Societatea de Investitii 
Financiare Oltenia S.A., S.C. ELECTROPUTERE S.A., S.C. MERCUR S.A., S.C. CONSTRUCTIII FEROVIARE S.A..

\section{Methodology of the Research}

Our research has aimed to reach the following objectives:

Objective no. 1: Knowing specialists' perception on the concept of "company's performance".

Objective no. 2: Identification of the reasons to implement an accounting model that integrates the exigencies of the accounting regulations.

Objective no. 3: Knowing the connection between the level of companies' responsibility and integration of the exigencies of accounting regulations into the accounting system.

In order to reach the three objectives, a quantitative research has been carried out, based on questionnaire. By means of this research instrument, I received answers in relation to increasing the level of companies' responsibility triggered by the integration of the exigencies of the regulations into the accounting practice.

The questionnaire has been randomly distributed to a number of 50 companies in the Dolj County, which have different fields of activity and belong both to the public and private sector. The questionnaire has been sent both online (via e-mail) and given in person, at the headquarters of the companies chosen randomly. The period for sending the questionnaires was as of January $1^{\text {st }}, 2017$ until July $1^{\text {st }}, 2017$.

By means of this quantitative research, it has been aimed to identify the perception of accounting professionals on the reaction triggered by integrating the exigencies of the accounting regulations into the accounting practice against the level of companies' responsibility.

The questionnaire has been structured into three parts as an answer to the preset objectives and related assumptions. The questions gave the respondents the possibility to select or tick one or several answers to the same question.

The first part of the questionnaire was designed to find out how the accounting specialists generally perceive the company's performance. Based on the answers received, it shall be determined if the first assumption of the research is validated, respectively: "Company's performance" is the profit of the financial year.

The second part of the questionnaire made it possible to determine whether the integration of the exigencies of accounting regulations ensure the satisfaction of the requirements of all information users. Thus, the following four exigencies of the accounting regulations have been listed within the questionnaire:

- accounting the gains and losses directly into the equity;

- the effect of amending the accounting policies and of correcting the fundamental errors on the result of the period;

- the moment of knowing the incomes and expenses in the accounting;

- determining the tax on deferred profit.

Based on the results obtained, it is verified whether the integration of these exigencies of the accounting regulations ensure meeting the requirements of all information users and whether the second assumption of the quantitative research is validated, respectively: The integration of the exigencies of accounting regulations ensures meeting the requirements of all information users.

The thirds part of the questionnaire aims to determine whether the four exigencies of the accounting regulations are integrated into the current accounting system of the company. Based on the answers received, the influence of integrating the exigencies of accounting regulations on the level of companies' responsibility is also assessed based on the answers received. In this regard, a question regarding the accounting professionals' perception has been inserted into the questionnaire about increasing the level of companies' responsibility after integrating the exigencies of the regulations into the accounting practice. At this question, the respondents had two variants to 
answer: YES or NO. The results obtained have allowed the appreciation of the level of validating the last research assumption: Integrating the exigencies of the accounting regulations into the accounting system increases the companies' level of responsibility.

The final part of the interview includes information on the profile of both the respondents and the company they represent. Information on the number of company's employees, form of property and its field of activity is presented. The respondent's position within the company is also presented, along with the educational level, seniority of service and seniority at the current job, age and gender.

With the help of the general questions, we wanted to highlight the following information on the 50 companies and individuals within the companies the questionnaires have been distributed to:

- the number of company's employees: most of the companies have more than 250 employees $(58 \%), 20 \%$ of the companies have between 10 and 50 employees, $12 \%$ of the companies have between 50 and 250 employees, and $10 \%$ of the companies have less than 10 employees;

- the company's form of ownership: $60 \%$ are companies of private ownership, $36 \%$ are companies of public ownership, 4\% are companies of mixed ownership;

- company's field of activity: public administration, trade, constructions, financialbanking services, education, forestry, rail transport, car service, medical services, railway transport, etc;

- position of the respondent within the company: 50\% of the respondents are economic managers, $38 \%$ are managers, $8 \%$ are economists, $4 \%$ occupy another position (administrator, head of the financial-accounting department;

- respondent's educational profile: $60 \%$ are graduates of economic higher education of $\mathrm{BA}$ and MA, $16 \%$ are graduates of economic BA higher and postgraduate education, $8 \%$ are doctors in economics, $16 \%$ are graduates of other specialisations and forms of education;

- respondent's experience in the field where they carry out their activity: $90 \%$ have experience over 10 years, $6 \%$ have experience between 5 and 10 years and $2 \%$ have experience between 1 and 5 years;

- the respondent's experience in the current job: $86 \%$ have experience over 10 years, $10 \%$ have experience between 5 and 10 years and 4\% have experience between 1 and 5 years;

- respondent's age: 58\% have ages between 41 and 50, 20\% have ages between 31 and 40, $18 \%$ have ages between 50 and $4 \%$ have their age under 30 ;

- respondent's gender: $58 \%$ are women and $42 \%$ are men.

\section{Results of the Research}

In order to achieve the objectives proposed, several aspects have been subject to analysis, according to table no. 1 .

Table 1

The Objectives of the Research and Questions Related to the Objectives

\begin{tabular}{|c|c|}
\hline ives & Questions A \\
\hline $\begin{array}{l}\text { I. Knowing specialists' } \\
\text { perception on the concept of } \\
\text { "company's performance". }\end{array}$ & $\begin{array}{l}\text { 1. What is the meaning you give to "company's } \\
\text { performance"? (select one of the answering variants) }\end{array}$ \\
\hline $\begin{array}{l}\text { II. Identification of the reaso } \\
\text { to implement an accounti } \\
\text { model that integrates } \\
\text { exigencies of the accounti }\end{array}$ & thin the \\
\hline
\end{tabular}




\begin{tabular}{|c|c|}
\hline regulations. & $\begin{array}{l}\text { regulations: } \\
\text { - accounting the gains and losses directly into the equity; } \\
\text { - the effect of amending the accounting policies and of } \\
\text { correcting the fundamental errors on the result of the period; } \\
\text { - the moment of knowing the incomes and expenses in the } \\
\text { accounting; } \\
\text { - determining the tax on deferred profit. }\end{array}$ \\
\hline $\begin{array}{l}\text { III. Knowing the connection } \\
\text { between the level of companies' } \\
\text { responsibility and integration of } \\
\text { the exigencies of accounting } \\
\text { regulations into the accounting } \\
\text { system. }\end{array}$ & $\begin{array}{l}\text { 1. Are these exigencies of the accounting regulations } \\
\text { integrated into your company's activity? (to formulate the } \\
\text { answer to this question, the exigencies of the accounting } \\
\text { regulations shown in the previous question shall be taken into } \\
\text { account). } \\
\text { 2. If the answer to the previous question is "NO", please } \\
\text { specify how these exigencies could be integrated into the } \\
\text { accounting system? (select one of the answering variants) } \\
\text { 3. Do you consider that the level of the cost for integrating the } \\
\text { exigencies of the regulations into the accounting practice can } \\
\text { be borne by your company now? } \\
\text { 4. Do you think that the integration of the exigencies of the } \\
\text { accounting regulations into the accounting system increases } \\
\text { the companies' level of responsibility? } \\
\text { 5. Within your company, is there an accounting department } \\
\text { consisting of specialists with skills and responsibilities } \\
\text { corresponding to the process of integrating the exigencies of } \\
\text { the accounting regulations? }\end{array}$ \\
\hline
\end{tabular}

Source: Own projection

Based on the questions formulated, reaching the research objectives as well as the related hypotheses was taken into account. Thus, after centralising the answers provided by those interviewed, we outlined an image on appreciating the company's performance, establishing the reasons for implementing an accounting practice that integrates the exigencies of the accounting regulations, as well as the relationship existing between the companies' level of responsibility and integration of the exigencies of accounting regulations into the accounting system.

The answers provided by the participants in the questionnaires achieved the objectives pursued by the research.

Objective I: Knowing specialists' perception on the concept of 'company's performance". To analyse this objective, those interviewed were asked the following questioned:

1. What is the meaning you give to "company's performance"? 
Select the meaning you give to the «company's performance»

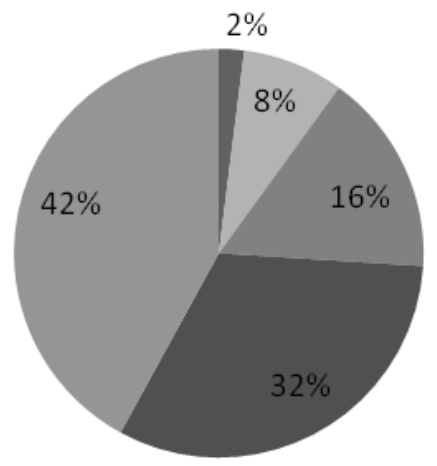

- Other (meeting customer's recuirements in optimal conditions)

$\square$ Gains from the capital (creating value)

- Sustainable presence on the market

- Profit of the financial year

Satisfying the customers, employees, investors and users of financial-accounting information

Figure no. 1 - The meaning of the «company's performance»

Source: Own projection based on the answers to the questionnaires

Following the answers to the first question about the significance given to the "performance of the company", $42 \%$ of the respondents consider that the performance of the company is to satisfy the customers, employees, investors and users of financial-accounting information, $32 \%$ consider that company's performance is the profit of the financial year, $16 \%$ the profit of the financial year, $8 \%$ the gains from the capital and only $2 \%$ give another meaning to the "company performance", such as satisfying the customer's requirements in optimum conditions.

Objective II. Identification of the reasons to implement an accounting model that integrates the exigencies of the accounting regulations.

1. What are the reasons for using the exigencies of the accounting regulations into the accounting practice within the company?

Reasons for using the exigencies of the accounting regulations in the accounting practice within the company

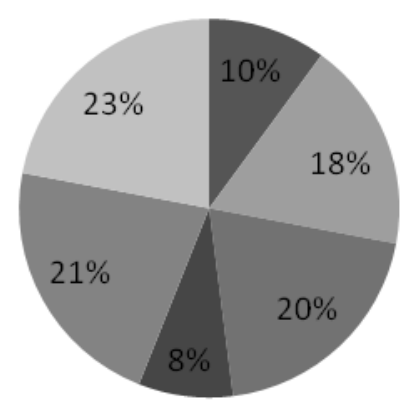

To involve the company into the process of sustainable development

To reach the strategic objectives

- To maintain the state of company's competitiveness

- To make predictions under the conditions of risk and uncertainty

To reflect the performance in the past, present and future

To satisfy the desires of all information users

Figure no. 2 - Reasons for using the exigencies of the accounting regulations in the accounting practice within the company

Source: Own projection based on the answers to the questionnaires

$23 \%$ of those interviewed consider that the exigencies of the accounting regulations are used in the accounting practice within the company to meet the desires of all information users, and $21 \%$ to reflect the performance in the past, present and future. $20 \%$ of the respondents consider that the exigencies of the accounting regulations are used in the accounting practice within the company to maintain the company's competitiveness state, $18 \%$ to reach the strategic objectives, $10 \%$ to 
employ the company in the process of sustainable development and $8 \%$ to make predictions under conditions of risk and uncertainty.

Objective III. Knowing the connection between the level of companies responsibility and integration of the exigencies of accounting regulations into the accounting system.

1. Are the exigencies of the accounting regulations integrated into the activity of your company?

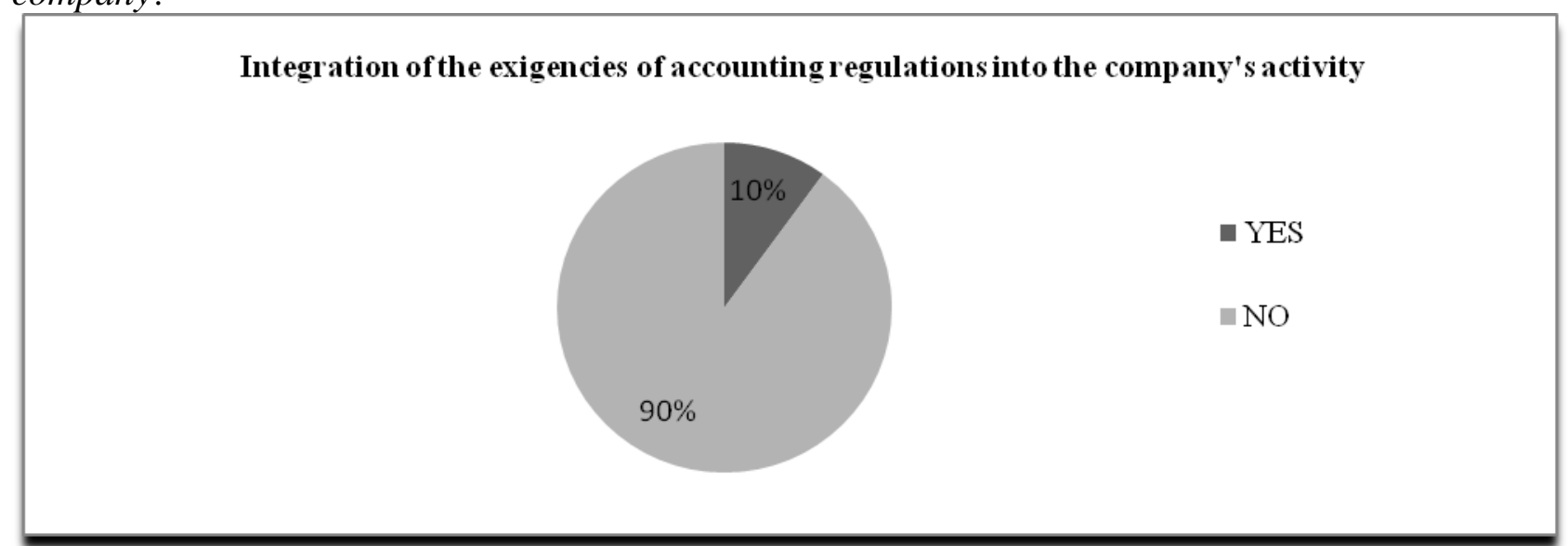

Figure no. 3 - Integration of the exigencies of accounting regulations into the company's activity

Source: Own projection based on the answers to the questionnaires

Most respondents affirm that the exigencies of the accounting regulations are not integrated into the activity of your company (90\%). A small number of respondents $(10 \%)$ affirm that the exigencies of the accounting regulations are integrated into the activity of the company.

2. If the answer to the previous question is "NO", please specify how these exigencies could be integrated into the accounting system?

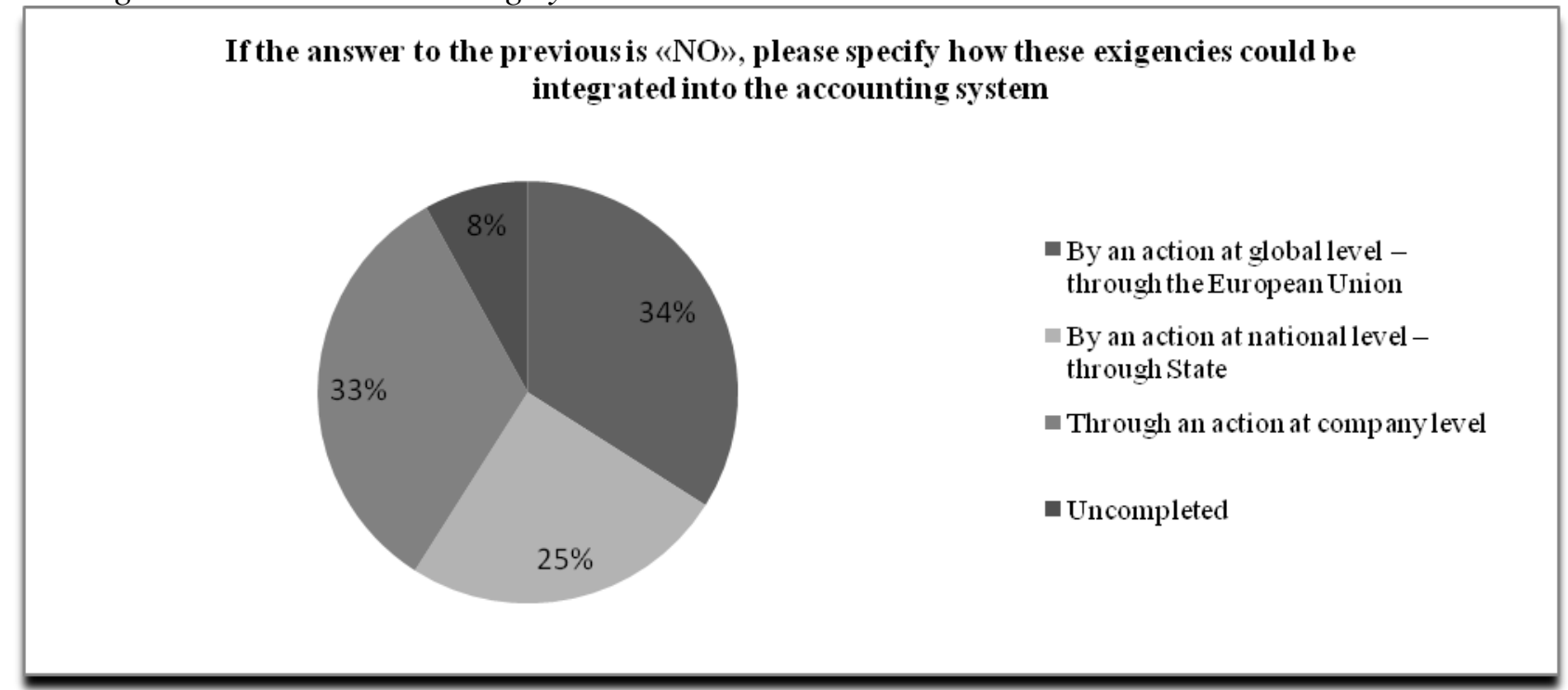

Figure no. 4 - The way that these exciencies could be integrated into the accounting system Source: Own projection based on the answers to the questionnaires

$34 \%$ of the respondents consider that the exigencies of the accounting regulations could be integrated into the accounting system through a global action - via the European Union, 33\% through an action at company's level, 25\% through a national action - through the state, and $8 \%$ did not answer this question. 
3. Do you consider that the level of the cost for integrating the exigencies of the regulations into the accounting practice can be borne by your company now?

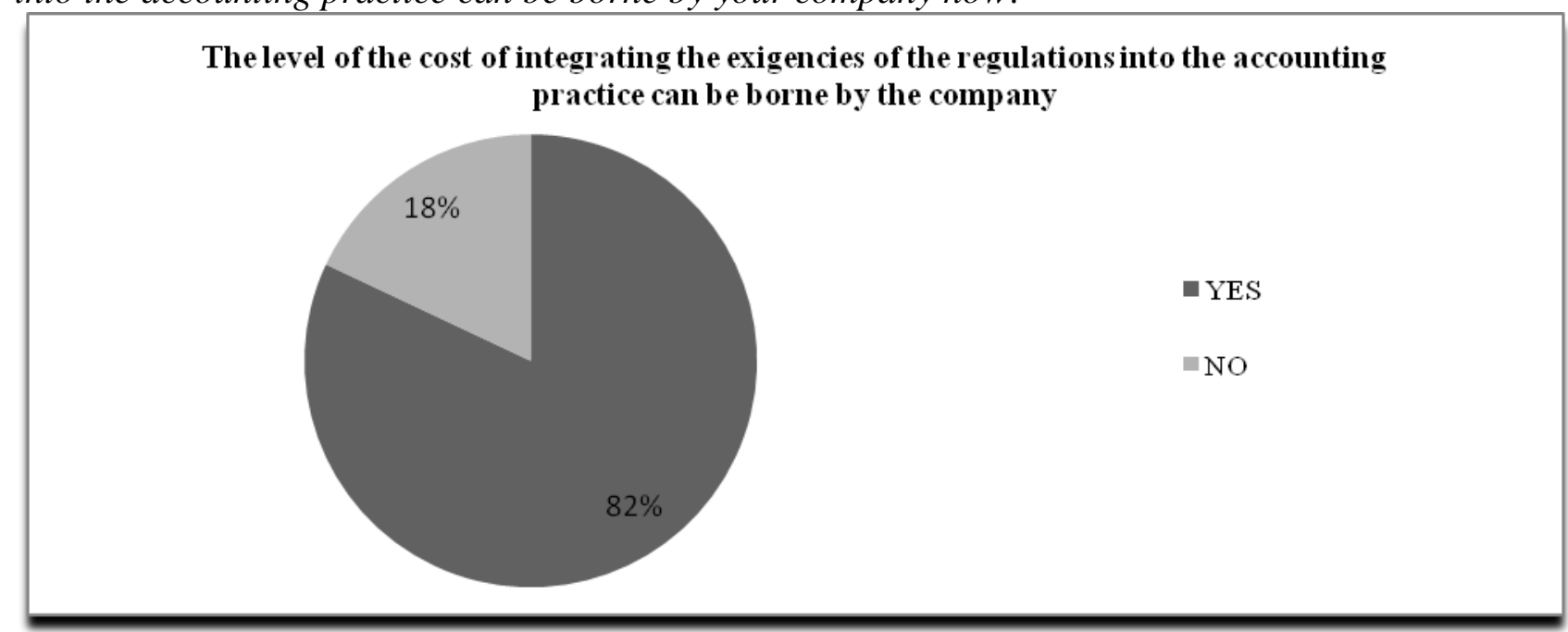

Figure no. 5 - The level of the cost of integrating the exigencies of the regulations into the accounting practice can be borne by the company

Source: Own projection based on the answers to the questionnaires

Most respondents (82\%) affirm that the level of the cost for the integration of the exigencies of regulations into the accounting practice can be borne by the company it represents, and $18 \%$ of the respondents consider that this cost cannot be borne by the company it represents.

4. Do you think that the integration of the exigencies of the accounting regulations into the accounting system increases the companies' level of responsibility?

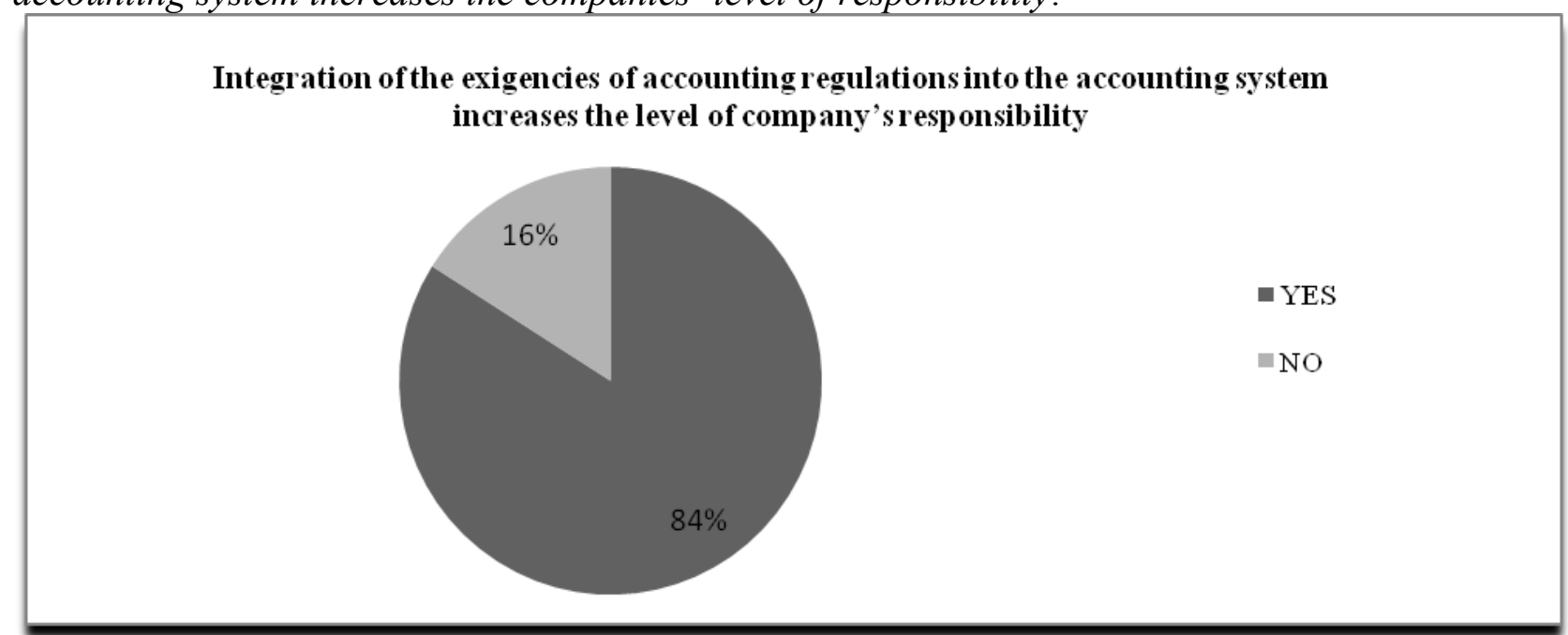

Figure no. 6 - Integration of the exigencies of accounting regulations into the accounting system increases the level of company's responsibility

Source: Own projection based on the answers to the questionnaires

$42 \%$ of the respondents consider that integration of the exigencies of accounting regulations into the accounting system increases the level of company's responsibility, and $16 \%$ of the respondents consider that the integration of the exigencies of the accounting regulations into the accounting system increases the company's level of responsibility.

5. Within your company, is there an accounting department consisting of specialists with skills and responsibilities corresponding to the process of integrating the exigencies of the accounting regulations? 


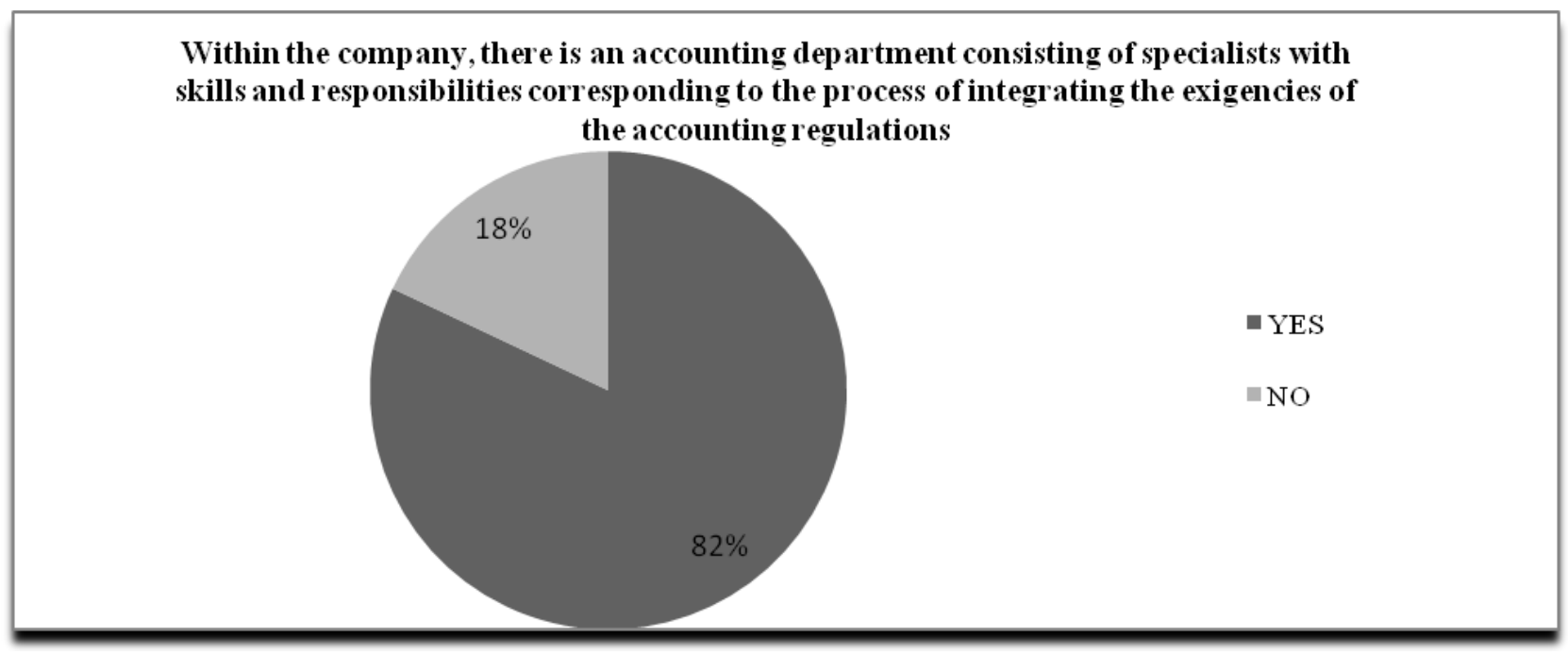

Figure no. 7 - The existence of an accounting department

Source: Own projection based on the answers to the questionnaires

$82 \%$ of the respondents affirm that within their company, there is an accounting department consisting of specialists with skills and responsibilities corresponding to the process of integrating the exigencies of the accounting regulations. $18 \%$ of the respondents affirm that within the company they represent, there is no such department.

\section{Conclusions}

Our research tries to draw the attention on the importance companies must give to the process of elaboration and decision-making substantiation. The assessment of the company's performance has an essential role in substantiating the decisions of all information users.

The results of the research carried out have invalidated the first assumption of the research and have validated the last two assumptions.

A higher percentage of those interviewed think that the company's performance is to satisfy the customers, employees, investors and users of financial-accounting information. Thus, based on the answers received to the first question of the questionnaire, the first assumption of the research is invalidated, respectively: "Company's performance" is the profit of the financial year.

Following the results received to the second question of the questionnaire, most of the respondents consider that the exigencies of the accounting regulations should be integrated into the accounting practice within the company in order to meet the requirements of all information users. Thus, the second assumption of research is validated, respectively: The integration of the exigencies of accounting regulations ensures meeting the requirements of all information users.

Most of those interviewed believe that integrating the exigencies of the accounting regulations into the accounting system increases the companies' degree of responsibility Thus, the third assumption of research is validated, respectively: "Integrating the exigencies of the accounting regulations into the accounting system increases the companies' level of responsibility."

Generally, the exigencies of the accounting regulations are not integrated into the activity of the companies interviewed. In the companies where these exigencies are not applied, they could be integrated into the accounting system through a global action - through the European Union. The cost of integrating these exigencies of the accounting regulations could be borne by the companies, particularly because they have in their organisational structure an accounting department consisting of specialists with skills and responsibilities corresponding to the process of integrating the exigencies of the accounting regulations. It is desired that the exigencies of the accounting 
regulations to be integrated into the company's activity in order to accurately assess the company's performance and increase its level of social responsibility.

In order to formulate the answers to the questions in the questionnaire, most respondents used the knowledge acquired throughout the higher and postgraduate education, as well as the knowledge acquired in the practical activity.

The accounting professionals, managers as well as the users of financial and accounting information shall need to be made aware of the importance that should be given to the process of integrating the exigencies of the accounting regulations into the companies' accounting system, in order to get a more accurate image of the company's performances.

We consider that in order to cope with the global competition, the companies need to be accountable by integrating the exigencies of the accounting regulations into the accounting practice. Thus, companies shall be able to determine and interpret more accurately the performance of the activity carried out.

We appreciate that the integration of the exigencies of the accounting regulations into the accounting practice is the key to companies' success in order to provide information to all decisionmakers. Thus, the accounting services within the companies need to be provided at the high quality standards and regularly updated in order to adapt to the requirements of all information users.

Through the conclusions provided, the research methodology presented in this article provides information that can ensure the decision-making support to the decision-makers for a steady increase in the company's performances.

One of the limits of our research consists in the fact that the target group has consisted only of specialists of the companies located in Dolj County. We intend to expand the target group in the future also with specialists from the companies located in other counties.

Future researches shall take into account the use of modern statistical instruments that would provide additional information in order to substantiate some more relevant conclusions.

\section{Bibliography}

1. Consiliul pentru Standarde Internaționale de Contabilitate (IASB), 2015. Standarde Internationale de Raportare Financiară (IFRS). Norme oficiale emise la 1 ianuarie 2015, traducere CECCAR. București, Editura CECCAR.

2. Petre Georgeta, Pavel Nicoleta, 2015. Contabilitatea rezultatului exercitiului și a rezultatului reportat în condițiile aplicării reglementărilor contabile conforme cu standardele internaționale de raportare financiară, Revista Finanțe publice și Contabilitate, nr. $3 / 2015$.

3. ***Instrucțiunea Autorității de Supraveghere Financiară (ASF) nr. 1/2015 pentru modificarea și completarea Instrucțiunii Autorității de Supraveghere Financiară nr. 2/2014 privind aplicarea Standardelor Internaționale de Raportare Financiară de către entitățile autorizate, reglementate și supravegheate de Autoritatea de Supraveghere Financiară din Sectorul Instrumentelor și Investițiilor Financiare, publicată în Monitorul Oficial, Partea I, nr. 343 din 19 mai 2015.

4. ***Ordinul Ministrului Finanțelor Publice nr. 666/2015 privind aplicarea Reglementărilor contabile conforme cu Standardele internaționale de raportare financiară de către unele entități cu capital de stat, publicat în Monitorul Oficial, Partea I, nr. 442 din 22 iunie 2015.

5. ***Ordinul Ministrului Finanțelor Publice nr. 1802/2014 pentru aprobarea Reglementărilor contabile privind situațiile financiare anuale individuale și situațiile financiare anuale consolidate, publicat în Monitorul Oficial, Partea I, nr. 963 din 30 decembrie 2014.

6. ***Ordinul Ministrului Finanțelor Publice nr. 2844/2016 pentru aprobarea Reglementărilor contabile conforme cu Standardele Internaționale de Raportare Financiară, publicat în Monitorul Oficial, Partea I, nr. 1020 din 19 decembrie 2016. 